Соціально-психологічні прояви дезадаптації проявляються у вигляді порушень міжособистісних відносин, посиленні внугрішньоособистісної конфліктності, незадоволеності обраною професією, труднощами в опануванні програмами навчання, незадоволеністю побутовими і соціальними умовами життя. Зазначені прояви $є$ пріоритетними у більшості студенток на першому і на другому курсах.

Висновки: 1. Навчальну діяльність студентів першокурсників можна розглядати як природну модель емоційного та інформаційного психологічного стресу, що у ряді випадків може привести до роз-

\section{Лiтература}

1. Аршава I. Ф. Функціональні стани людини в процесі адаптації до екстремальних умов діяльності (у парадигмі “особистість-стан”) / І. Ф. Аршава // Вісник АПН України : Педагогіка і психологія. - К. : Педагогічна преса, 2006. №4(53). - С. $82-90$.

2. Волосовець О. П. Стратегія євроінтеграційного реформування вищої медичної освіти України / О. П. Волосовець // Проблеми медичної науки та освіти. - 2006. № 1. - С. 5 - 12 . ладів адаптації, які потребують психологічної та психотерапевтичної корекції.

2. Іноземні студенти - першокурсники, особливо які навчаються англійською мовою, у порівнянні 3 вітчизняними студентами більш важко адаптуються до умов навчання, схильні до розвитку невротичних реакцій, частіше відчувають труднощі в засвоєнні навчального матеріалу.

3. Отримані в ході роботи дані дозволяють спрогнозувати фактори виникнення розладів адаптації у студентів початкового періоду навчання у ВНЗ і визначити основні напрямки психопрофілактичних та психокорекційних заходів.

3. Дорожкин Ю. Н. Проблемы социальной адаптации иностранных студентов / Ю. Н. Дорожкин, Л. Т. Мазитова // Социологические исследования. - 2007. - № 3. - С. 73-77.

4. Кокун О. М. Адаптація та адаптаційні можливості людини : прикладні аспекти / О. М. Кокун // Актуальні проблеми психології. - Т. 5, вип. 4 : Психофізіологія. Медична психологія. Генетична психологія / за ред. С. Д. Максименка. -К. : Міленіум, 2005. - С. 77-85.

5. Соколова И. М. Психофизиологические механизмы адаптации студентов / И. М. Соколова . - Харьков : ХГМУ, 2007. -412 c.

УДК 37.032

\title{
ДО ПИТАННЯ ФОРМУВАННЯ МЕДИЧНОЇ ЕЛІТИ У ВНЗ: ПРОБЛЕМИ, ДОСВІД ТА ПЕРСПЕКТИВИ
}

В. М. Лісовий, В. А. Капустник, В. В . М'ясосдов Харківський національний медичний університет

\section{TO THE ISSUE OF THE NATIONAL ELITE FORMING IN THE HIGHER EDUCATIONAL INSTITUTION: PROBLEMS, EXPERIENCE AND PROSPECTS}

\author{
V. M. Lisovyi, V. A. Kapustnyk, V. V. Myasoyedov \\ Kharkiv National Medical University
}

У статті обгрунтовано необхідність та запропоновано шляхи формування національної еліти в системі вищої освіти.

In the article the necessity of national elite forming is grounded and the ways of its realizing in the system of higher education are given.

Вступ. Загальновідомо, що суттєвою ознакою зрілості будь-якої держави є наявність системи відтворення національної еліти. Саме національні провідни- ки, являючи собою відносно тонкий прошарок суспільства, практично формують і репрезентують образ своєї держави, ії майбутнє.

(с) В. М. Лісовий, В. А. Капустник, В. В . М'ясоєдов 
Український філософ В. Липинський, розвиваючи теорію еліт, зазначав, що керування перетворенням пасивного, хоч і відмінного від інших, але часто національно несвідомого, колективу в організовану, самосвідому націю виконує скрізь і завжди нова активна меншість, яка завдяки своїй матеріальній, моральній та інтелектуальній силі очолює націю і творить громадські цінності, які згодом переймаються пасивною більшістю нації, об' єднуючи ії в один суцільний національний організм [1].

Тому сьогодні, як і раніше, надзвичайно важливо сформувати національно свідому еліту, провідну верству, без якої неможливо по-справжньому реалізувати державотворчу національну ідею. Сьогодні саме це $є$ надзадачею університетської системи освіти, у тому числі і медичної. Зараз, як ніколи, потрібні молоді інтелектуальні лідери.

Про створення "у вищих навчальних закладах умов для залучення талановитої молоді до наукової та педагогічної діяльності” йдеться й у проекті Програми розвитку вищої медичної освіти до 2015 р. МО3 України [2].

Основна частина. Освітне середовище, яке складається, як мінімум, з двох компонентів - середньої та вищої освіти, є єдиним цілим. Тож, який би досконалий механізм вищої освіти ми би не запровадили, навряд чи вища школа зможе “виробити" високоякісний конкурентоспроможний освітній продукт без високоякісної “сировини”, тобто без підготовленого для навчання в умовах вищого навчального закладу абітурієнта.

У Європі престиж вищої освіти традиційно дуже високий. Там знають і розуміють, що отримати ії здатна не кожна людина. Середню освіту на високому рівні завершують лише ті випускники, які мають намір вступити до вищих навчальних закладів. Це приблизно 15-25 \% усіх учнів середніх шкіл. А кількість студентів, які завершують навчання у вищих навчальних закладах Європи, становить 50-60 \% від набору.

В Україні ж практично всі випускники шкіл з повною загальною середньою освітою орієнтовані на отримання вищої освіти. Останні роки кількість претендентів на вступ до вищих навчальних закладів за результатами тестування майже дорівнює кількості осіб, що стають студентами перших курсів вищих навчальних закладів України III-IV рівнів акредитації, тобто близько $100 \%$, що приблизно в 10 разів більше, ніж дозволяє природний розподіл інтелекту.

I хоч масова освіта підсилює ознаки цивілізаційної ідентичності нації, з іншого боку-суспільству потрібні високоосвічені фахівці, котрі б вирішували як актуальні, так і перспективні завдання економіки та куль- тури і отримували б за це вищу, у порівнянні з іншими, зарплатню. А така освіта може грунтуватися лише на базі природного інтелекту.

Крім унікальних здібностей і великої працездатності, майбутньому кандидатові до найвищого наукового світу для професійного росту потрібна організована система селекції, аби ще на ранніх стадіях талант мав шанс бути поміченим.

У Харківському національному медичному університеті розпочата практика створення груп з поглибленим вивченням навчальних дисциплін 3 метою удосконалення системи підтримки та розвитку талановитої та обдарованої молоді. Групи формуються на першому курсі за результатами зовнішнього незалежного тестування, на старших курсах - за результатами навчально-виховної та науково-дослідної роботи студентів за наявності їх письмової згоди. Організацію навчально-виховного процесу та науково-дослідної роботи груп з поглибленим вивченням навчальних дисциплін здійснює Координаційна рада на чолі 3 першим проректором з науково-педагогічної роботи. Для роботи в цих групах залучаються найбільш досвідчені викладачі. Склад викладачів за поданням кафедр розглядається на Координаційній раді та затверджується наказом ректора університету. Для реалізації програм поглибленого вивчення навчальних дисциплін залучається професорсько-викладацький склад інших вищих навчальних закладів, співробітники академічних науково-дослідних установ тощо. У навчальному процесі поряд з традиційними використовуються інноваційні технології, дослідно-експериментальні та творчі види діяльності студентів, їх участь у роботі наукових гуртків кафедр, у навчально-методичних конференціях, навчання в Школі молодих науковців. Для всебічного розвитку особистості студентів передбачено індивідуальний план гуманітарної підготовки, у т. ч. і поглиблене вивчення іноземної мови. Кожний студент повинен підготувати та захистити дві курсові наукові роботи на 2 і 3 курсах та дипломну роботу як результат особистих наукових досліджень на 6 курсі.

Склад цих груп не $є$ постійним. У випадках, коли студенти не опановують навчальної програми і мають за підсумками річного оцінювання знань навчальні досягнення не вище початкового рівня хоча б $з$ одного предмета, згідно з рішенням Координаційної ради та відповідним наказом ректора університету їх переводять до груп, які працюють за стандартними навчальними планами.

Одночасно Координаційною радоюз питань організації навчально-виховної та науково-дослідної діяль- 
ності в групах з поглибленим вивченням навчальних дисциплін розглядається питання про кооптацію в ці групи студентів, які мають добрі та відмінні показники успішності та навчаються в групах за стандартними навчальними планами, за їх письмовою згодою.

На нашу думку, виявлення обдарованих дітей та індивідуальна робота з ними - один із шляхів формування національної інтелектуальної еліти, майбутні здобутки якої дозволять нам посісти гідне місце в європейському науковому та освітньому співтоваристві.

Ще одним кроком у цьому є реалізація концепції "Навчання через дослідження" - одного з керівних принципів створення єдиного освітньо-наукового простору.

У Харківському національному медичному університеті 31929 р. існує Студентське наукове товариство (СНТ), яке є самокерованим суспільним об'єднанням студентів, створеним на основі спільності інтересів у сфері наукових досліджень. Основною метою роботи Ради СНТ є залучення талановитої молоді до сфери науки, створення умов для заняття науковою роботою та вдосконалення навичок студентів у самостійній науково-дослідній діяльності. У даний час СНТ ХНМУ налічує 926 осіб, які виконують наукову роботу в 62 студентських наукових гуртках.

Студенти та молоді вчені ХНМУ щорічно беруть активну участь у роботі Всеукраїнських наукових конференцій і форумів студентів та молодих вчених, детрадиційно посідають призові місця.

Справжньою кузнею формування молодіжної університетської еліти є Міжнародний науковий міждисциплінарний конгрес молодих вчених та студентівмедиків - International Scientific Interdisciplinary Congress (ISIC), який щовесни проводиться на базі Харківського національного медичного університету. Організаторами й активними учасниками цього форуму є студенти й молоді науковці університету.

Робота конгресу включає проведення наукових лекцій та майстер-класів провідними вченими Харківського національного медичного університету, провідних університетів, науково-дослідних інститутів України та країн Європи. Офіційна мова конгресу - англійська.

\section{Лiтература}

1. Липинський В. Листи до братів-хліборобів / В. Липинський // Політологія. Кінець ХІХ - перша половина ХХ ст. : хрестоматія.-Львів : Світ, 1996. - С. 328-477.
3 кожним роком збільшується кількість студентів та молодих вчених, які беругь участь у роботі конгресу. Під час проведення I Міжнародного наукового міждисциплінарного конгресу для молодих вчених та студентів-медиків (International Scientific Interdisciplinary Congress) у 2008 році в його роботі взяли участь близько 120 молодих вчених та студентів з різних куточків України, Росії, Білорусі, Польщі, Сербії та Чорногорії. У 2009 році кількість учасників збільшилась до 225 осіб, серед яких 74 - іноземці. 2010 року в конгресі взяло участь більше 250 молодих вчених та студентів 3 різних країн світу: України, Російської Федерації, Білорусі, Латвії, Германії, Швейцарії, Греції, Польщі, Болгарії, Румунії, Сербіі, Чорногорії, Туреччини, Сгипту та інших.

Метою проведення молодіжного наукового форуму такого формату є обмін досвідом та ознайомлення із сучасними досягненнями клінічної та фундаментальної медицини на основі обговорення результатів останніх досліджень молодіжної науки різних країн світу.

Не менш важливо і те, що участь у Конгресі дає можливість студентам поспілкуватися 3 молодими вченими з інших країн, визначити рівень своїх знань, впевнитися в тому, що в сучасному світі тільки інтелект та висока наукова, професійна кваліфікація можуть бути умовами професійного росту.

Оцінкою організації молодіжної науки в нашому університеті стала золота медаль міжнародної виставки “Освіта та кар'єра - 2010” (Київ, листопад 2010) у номінації "Розвиток студентської науково-дослідної роботи”.

Висновок. Підготовка національної еліти - найголовніша справа вищої школи, яка неможлива без підтримки держави. Необхідним вбачається розробка на державному рівні Концепції роботи з талановитою та обдарованою молоддю, яка не лише забезпечить умови для їі розвитку (правові, фінансові, соціальні), а й, найголовніше, створить робочі місця для іiі подальшої професійної реалізації саме в Україні.

2. Програма розвитку вищої медичної освіти до 2015 р. (проект) (веб-сайт МОЗ України). 